\title{
The Maceration Technique in Scanning Electron Microscopy of Collagen Fiber Frameworks: Its Application in the Study of Human Livers
}

\author{
Osamu Ohtani \\ Department of Anatomy, Faculty of Medicine, Toyama Medical and Pharmaceutical University, Toyama, Japan
}

Received February 4, 1992

\begin{abstract}
Summary. This paper reviews the cell-maceration/ scanning electron microscopic (SEM) technique and its application in the study of human livers. The maceration of glutaraldehyde-fixed tissues with $2 \mathrm{~N}-\mathrm{NaOH}$ and water at room temperature effectively and consistently removes all the cells, thus exposing collagen fiber networks. SEM of the macerated tissues shows threedimensional arrangements of collagen fibers more clearly than previously reported methods. High resolution SEM observations of macerated and non-macerated collagen fibrils of the rat tail tendon have revealed that both show similar cross-striated bandings that are determined by an alternate succession of elevated and depressed segments along the collagen fibrils, with a period of approximately $65 \mathrm{~nm}$. Three ridges have been observed in the nonmacerated collagen fibrils: two on the margins of the elevated segments and one at an intermediate point of the depressed segment. The macerated collagen fibrils show a straight arrangement with slightly wavy microfibrils.

The subendothelial spaces of Disse in the human liver contain abundant collagen fibers. There are some collagen fibers that stretch between adjacent collagen fiber sheaths in the subendothelial spaces of Disse, either forming a mono-layered network or coursing individually. The collagen fibers in the spaces of Disse are continuous with those in the liver capsule and in the Glisson's sheaths and with those around the central and sublobular veins. The collagen fibers in human livers form a network of the liver as a whole, thus constituting a hepatoskeletal system.
\end{abstract}

In the first half of this century, light microscopy of silverimpregnated preparations was the principal technique for the study of connective tissues (e.g., Holmgren, 1907; PlenK, 1927; NAGEL, 1934, 1935; ClARA, 1936); and the fine three-dimensional organization of the connective tissue could not be properly visualized.

Recently we established a cell maceration technique with a $\mathrm{NaOH}$ solution and water for scanning electron microscopic (SEM) observations of collagen fiber arrangements (OHTANI, 1987; OHTANI et al., 1988). As this method is able to remove cellular elements effectively and consistently, thus clearly exposing the collagen fibers, it has become widely employed and has revealed the three-dimensional organization of collagen fiber frameworks of various tissues (OHTANI, 1987, 1988; OHTANI et al., 1988, 1991; Kikuta, OHTANi and Murakami, 1991; Komai and UsHIKI, 1991; MoRITA et al., 1991).

This paper reviews the cell-maceration technique and shows its application to the study of human livers.

\section{MATERIALS AND METHODS}

The materials used were human livers obtained in the autopsy of a Japanese female subject who died of urinary bladder cancer at 72 years of age and of a Japanese male of 70 years of age. Routine light microscopy showed that the human materials had no significant pathological changes. The tail tendon was obtained from two male Wistar rats $(250 \mathrm{~g}$ body weight).

The collagen fiber networks of tissues were extracted and observed according to our cell-maceration/SEM method as previously described (OHTANI, 1987; OHTANi et al., 1988). The preparation procedures were as follows: 1 ) The tissues were fixed in $2.5 \%$ glutaraldehyde or $4 \%$ paraformaldehyde in a 0.1 $\mathrm{M}$ phosphate buffer ( $\mathrm{PB}, \mathrm{pH}$ 7.3) by either perfusion or immersion. They were then cut into small pieces 
measuring $2 \times 3 \times 5-5 \times 5 \times 5 \mathrm{~mm}^{3}$ and further immersion-fixed in the same fixative for a day or two. 2) The pieces were immersed in $2 \mathrm{~N}-\mathrm{NaOH}$ for 3-7 days at room temperature (about $25^{\circ} \mathrm{C}$ ). 3) The $\mathrm{NaOH}$-treated tissues were put in distilled water for $3-4$ days at room temperature (about $25^{\circ} \mathrm{C}$ ). All of the cells were removed at this step, thus leaving only whitish, semitransparent collagen fiber networks. 4) The extracted collagen fiber networks were immersed in $0.5-1 \%$ tannic acid solution for 1-2 h. 5) After rinsing in distilled water for several hours, they were fixed in $1.0 \% \mathrm{OsO}_{4}$ for $1-2 \mathrm{~h}$. 6) They were dehydrated through graded concentrations of ethanol. 7) They were then freeze-cracked in liquid nitrogen with a razor blade. 8) They were critical-point-dried using liquid $\mathrm{CO}_{2}$ or freeze-dried in t-butyl alcohol (WHEELER et al., 1975; INOUE and OsATAKE, 1988). 9) The preparations were mounted on specimen-holders for SEM with silver paste. 10) They were coated with gold to an approximately $2 \mathrm{~nm}$ thickness and observed in a Hitachi S-900 or S-2300 SEM with an accelerating voltage of $15-20 \mathrm{kV}$. Stereo-pairs of micrographs were frequently taken with a tilt separation of $4-7^{\circ}$.

To compare $\mathrm{NaOH}$-macerated collagen fibrils with non-macerated ones, some of the rat tail tendons were prepared for usual SEM observations. The tendons were rinsed in $0.9 \%$ saline, and fixed in $2.5 \%$ glutaraldehyde in $0.1 \mathrm{M}$ PB. They were postfixed in $\mathrm{OsO}_{4}$ and dehydrated through graded concentrations of ethanol. After critical-point-drying in liquid $\mathrm{CO}_{2}$, they were mounted on specimen-holders with silver paste, coated with gold to a $2 \mathrm{~nm}$ thickness, and observed in a Hitachi-900 SEM with an accelerating voltage of $20 \mathrm{kV}$.

\section{RESULTS AND DISCUSSION \\ Comparison of macerated collagen fibrils with non-macerated ones}

High resolution SEM of non-macerated collagen fibrils of the rat tail tendon showed that the tendon consisted largely of thick collagen fibrils $100-250 \mathrm{~nm}$ in diameter, and scattered thin ones approximately $30 \mathrm{~nm}$ in diameter. There were cross striated bandings which were determined by an alternate succession of elevated and depressed segments along the collagen fibrils, with intervals of approximately 65 nm (Fig. 1). Two ridges were noticed at the margins
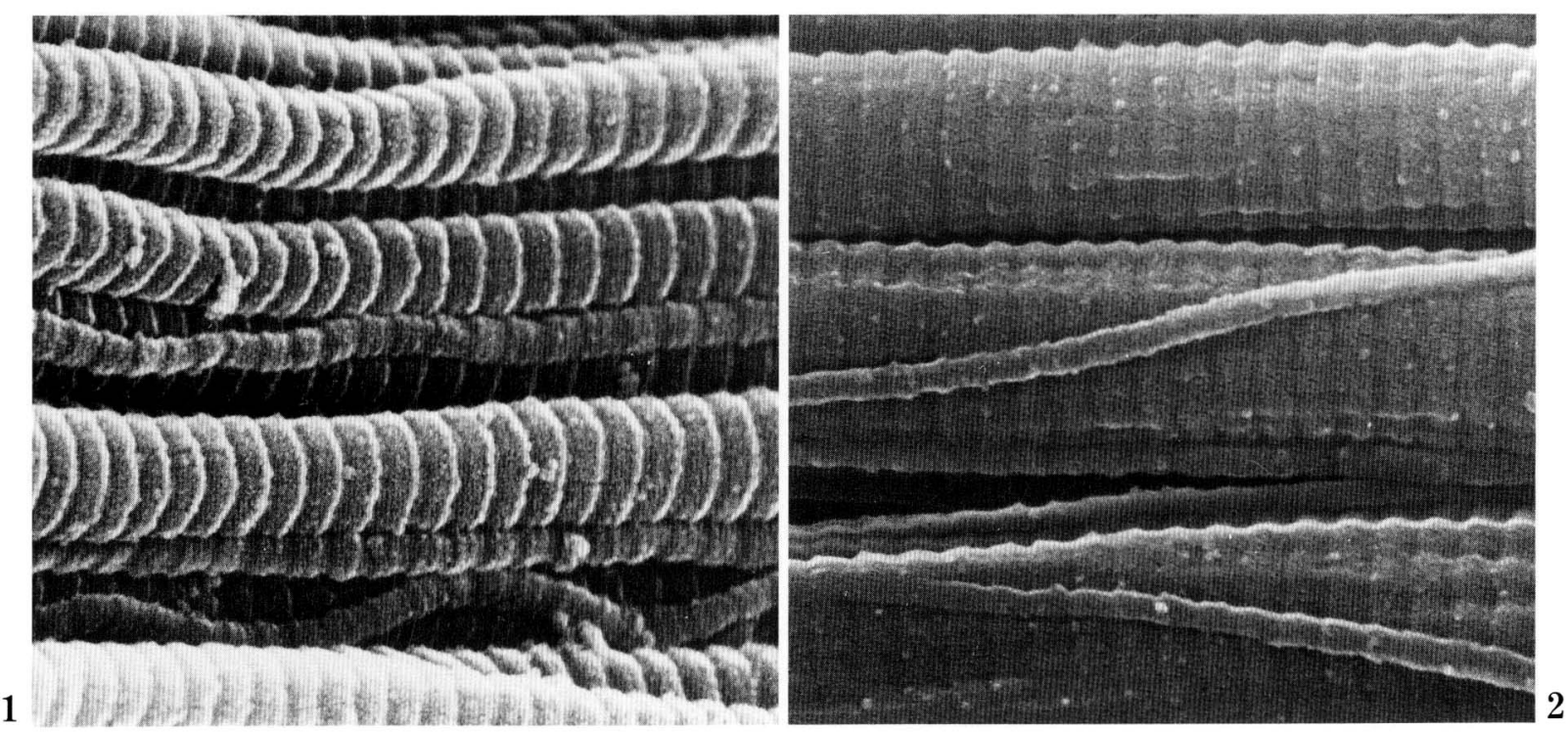

Fig. 1. High-resolution SEM view of non-macerated collagen fibrils from the rat tail tendon. Note crossstriated bandings consisting of an alternate succession of elevated and depressed segments along the collagen fibrils. Note also that there are two ridges at the margins of the elevated segment and a third ridge at an intermediate point of the depressed segment. $\times 84,000$

Fig. 2. High-resolution SEM view of $\mathrm{NaOH}$-macerated collagen fibrils from the rat tail tendon. Along the collagen fibrils are cross-striated bandings that can be determined by an alternate succession of elevated and depressed segments. A straight arrangement with slightly wavy "microfibrils" can be seen in the collagen fibrils. $\times 84,000$ 
of the elevated segments of the collagen fibrils, and a third ridge was situated at an intermediate point of the depressed segments (Fig. 1). These three ridges seemed to correspond to the three widest light bands observable in negatively stained collagen fibrils and also to the ridges observed in deep-etched ones (MARCHINI and RUGGERI, 1984).

SEM of macerated rat tail tendon also showed the bandings determined by the alternate succession of elevated and depressed segments along the collagen fibrils with intervals of approximately $65 \mathrm{~nm}$ (Fig. 2). However, the ridges were less prominent than those seen on the non-macerated collagen fibrils. Occasionally, thin collagen fibrils of approximately $30 \mathrm{~nm}$ in diameter branched off from thicker ones (Fig. 2).

A straight arrangement with slightly wavy "microfibrils" was observed in the collagen fibrils of the rat tail tendon (Figs. 1, 2). The "microfibrils" were more clearly observed in the macerated-collagen fibrils than in non-macerated ones. This type of microfibrillar arrangement is perhaps characteristic to Type I collagen, as suggested by MARCHINI and RUGGERI (1984).

Although the macerated collagen fibrils slightly differed morphologically from non-macerated ones, both showed cross-striated banding patterns characteristic to collagen fibrils. These data indicate that preparations with the maceration technique consist of actual collagen fibrils, and that the method is therefore applicable to demonstrating collagen fibrils. In addition, high-resolution SEM of the macerated collagen fibrils is able to disclose the arrangements of collagen "microfibrils".

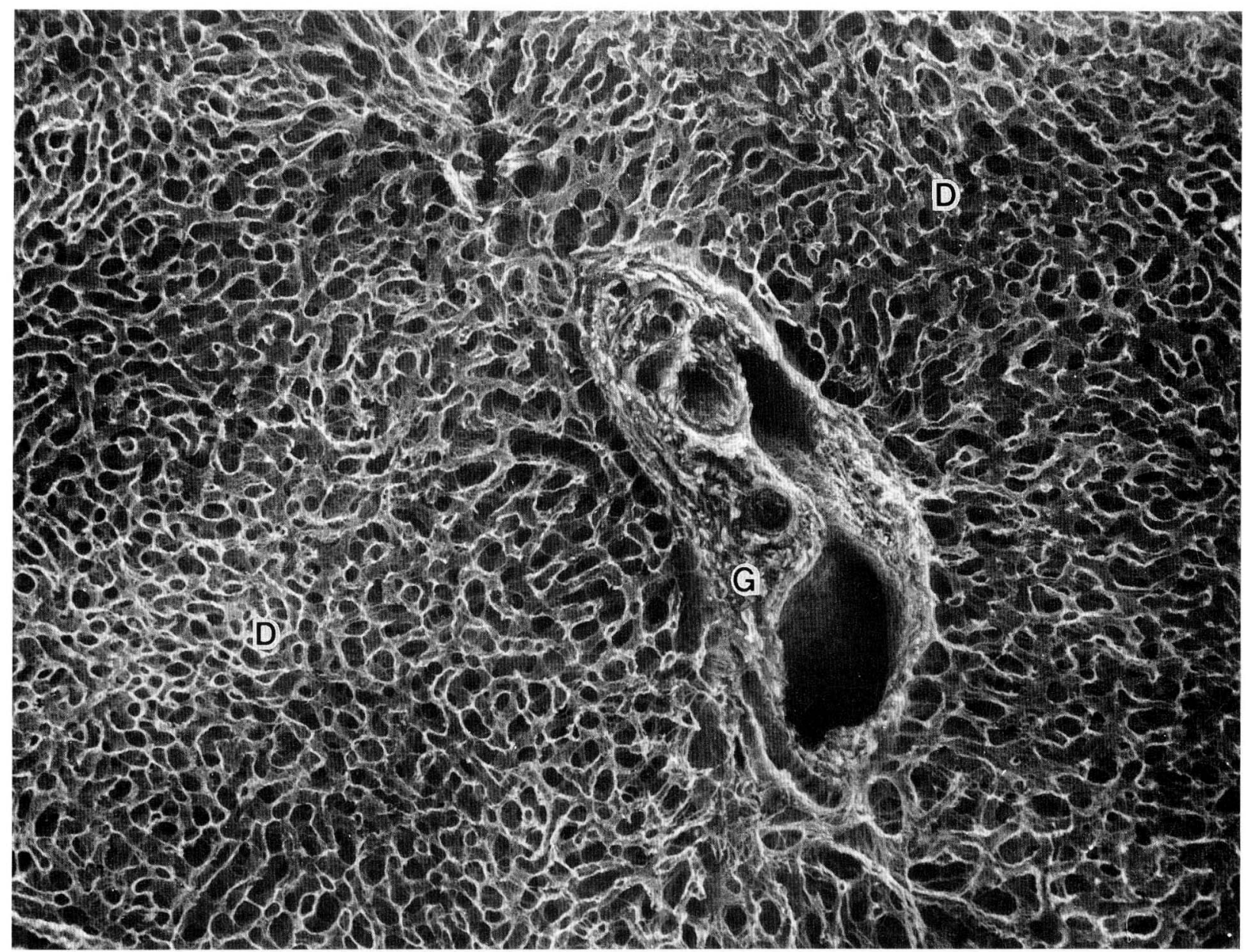

Fig. 3. SEM view of the collagen fiber network of the human liver. There is a condensation of collagen fibers in the Glisson's sheath $(G)$. The collagen fibers in the spaces of Disse $(D)$ form sheaths for housing the hepatic sinusoids. (From O. Ohtani: Arch. Histol. Cytol., 51, 1988) $\times 150$ 


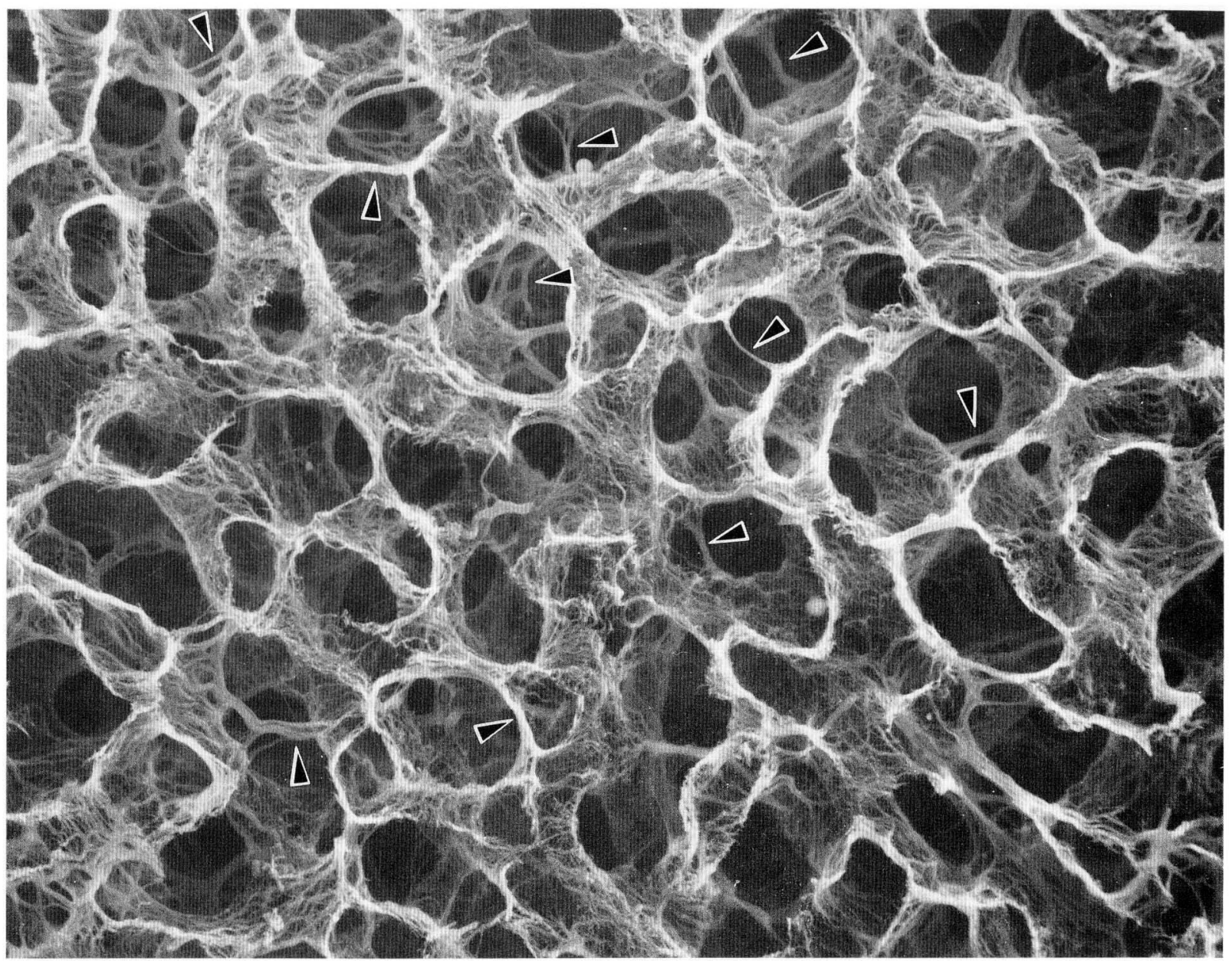

Fig. 4. SEM view of the collagen fiber network of the human liver. Note collagen fibers stretching between adjacent sheaths for the sinusoids as indicated by arrowheads. $\times 750$

\section{Advantages and disadvantages of the cell-macera- tion/SEM technique}

Many authors have attempted to remove cellular elements to expose the connective tissues, employing acetic acid (HoRSTMANN, 1952), trypsin (SCHENK and WERSALL, 1975), EDTA (KLEIN-SZANTO and SCHROEDER, 1977), prolonged fixation in $\mathrm{OsO}_{4}$ followed by ultrasonication (HIGHISON and Low, 1982), maceration in boric acid plus ultrasonication (LOW and MCCLUGAGE, 1984), or washing with a jet of Ringer's solution (Miyoshi and Shingu, 1984). Our experiments have revealed that the cell-maceration technique herein reviewed is able to remove all of the cells effectively and consistently, and thus exposes the collagen fibers and fibrils more clearly than any other methods so far reported. SEM observations of the preparations with the cell-maceration technique can demonstrate threedimensional arrangements of collagen fibrils, regard- less of whether they form bundles (i.e., collagen fibers) or course individually (Figs. 3-5). Thus the cell-maceration/SEM technique is highly useful for demonstrating three-dimensional arrangements of collagen fibers. Furthermore, the technique is applicable for revealing the arrangements of collagen "microfibrils".

Since all of the cells are removed by the cellmaceration/SEM technique, it cannot demonstrate exact spatial relationships between collagen fibers and cellular elements. Such relationships should be examined by light and transmission electron microscopy of tissues. In order to overcome this disadvantage, we frequently employ combined methods of light microscopy with the cell-maceration/SEM technique. Here, a thin section of tissue block is cut with a vibratome and processed for light microscopy, while the remaining tissue block is treated with the cell-maceration technique in order to observe the 


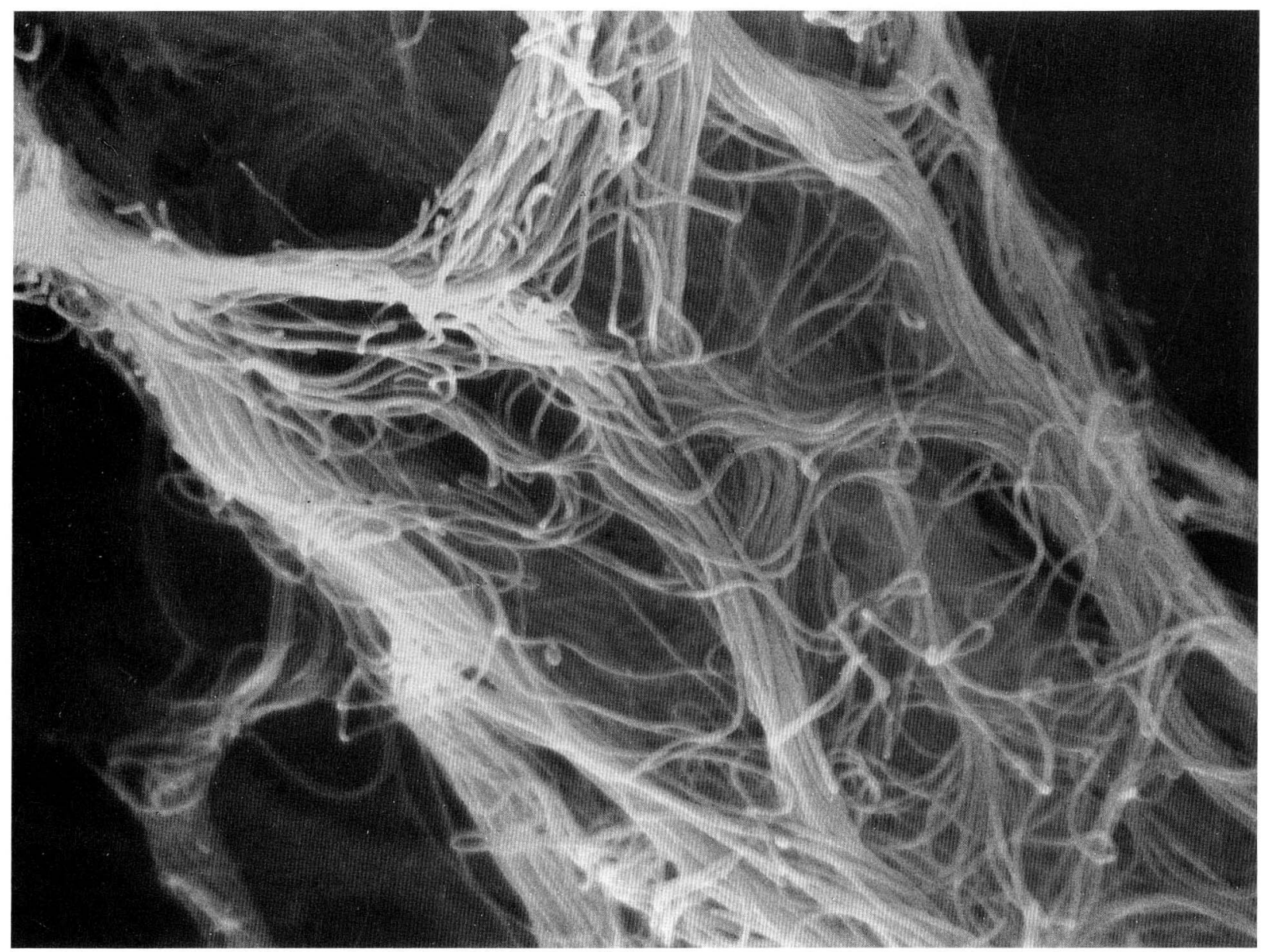

Fig. 5. High magnification/SEM view of the collagen fibers forming a sheath for the sinusoid. Collagen fibers form meshworks, each of which contains winding collagen fibrils that run individually. $\times 11,300$ (From 0 . Ohtani, Arch. Histol. Cytol., 51, 1988).

consecutive surface under SEM. The disadvantage can be also overcome to some extent by comparing the arrangements of collagen fiber networks with those of cellular elements exposed by HCl-collagenase (EvAN et al., 1976) or alkali-collagenase treatment (Miller et al., 1982).

\section{Collagen fiber arrangements of the human liver}

As was shown in our previous study (OHTANI, 1988), there were many more collagen fibers in the human liver than commonly believed. In the Glisson's sheath was a condensation of collagen fibers, their diameters being 1 to $5 \mu \mathrm{m}$ (Fig. 3). There were some channels for the portal vein branches, the hepatic arterial branches, the bile ducts and lymphatic vessels in the Glisson's sheath. They were lined by a fine meshwork of interwoven collagen fibrils. Collagen fibers in the periphery of Glisson's sheath were continuous with those in the spaces of Disse (Fig. 3).

In the subendothelial spaces of Disse, there were collagen fiber sheaths surrounding the hepatic sinusoids (Figs. 3-6). At low magnification, these sheaths for the sinusoids appeared to consist of a thin continuous membrane (Figs. 3, 4). At higher magnifications, collagen fibers (approximately $0.2-2 \mu \mathrm{m}$ in diameter) repeatedly divided and fused to form meshworks (Figs. 4, 5). Each mesh contained some winding collagen fibrils that coursed individually (Fig. 5). The mesh was presumably juxtaposed to the sieve plate of the hepatic sinusoids. There were no special condensations of collagen fibers that demarcated the hepatic lobule. However, there were some regional differences in the organization of the collagen fiber sheaths for the sinusoids. Near their origins at the portal vein branches, the sheaths for 


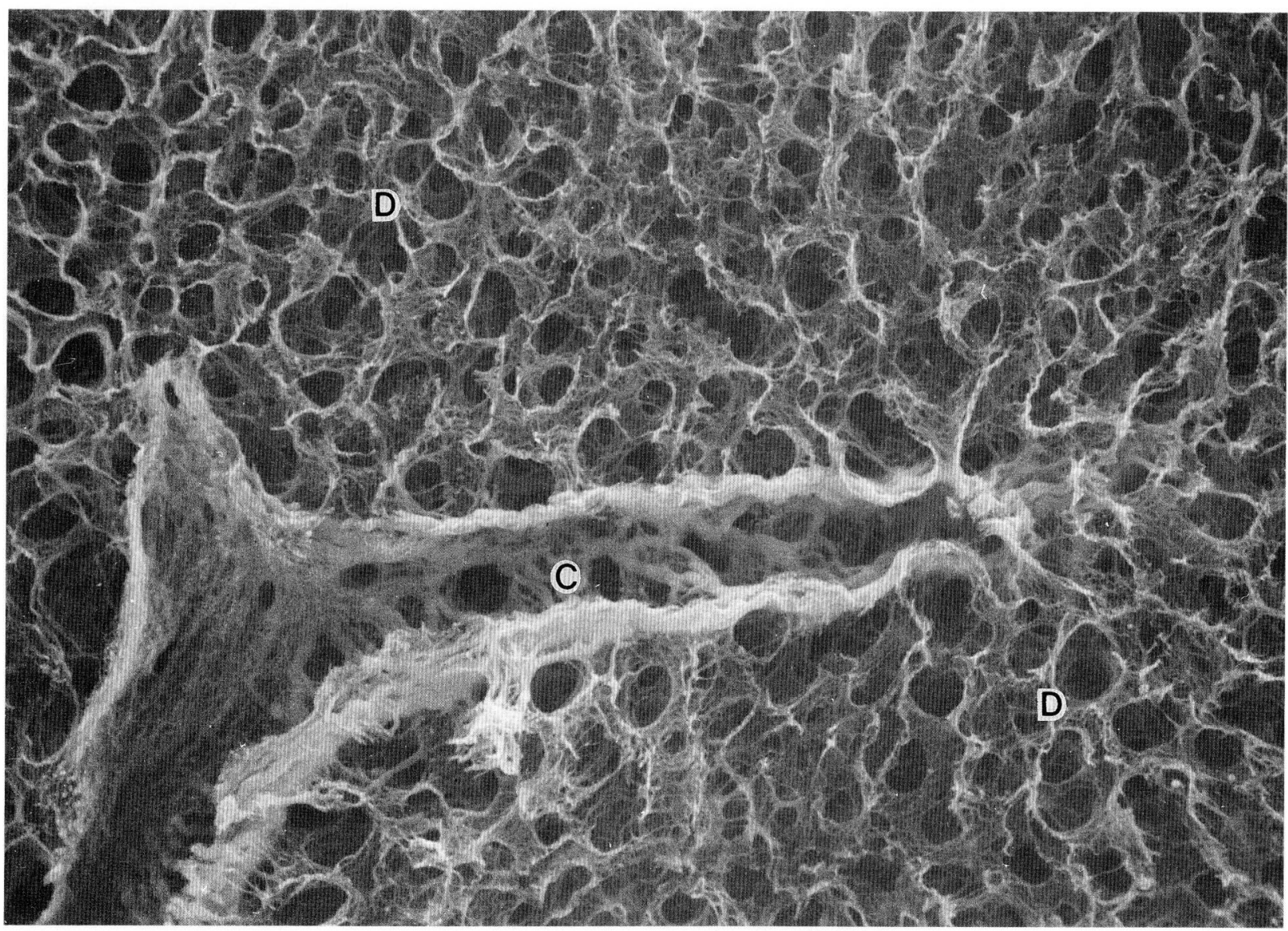

Fig. 6. SEM view of collagen fibers of the human liver. There is a condensation around the central vein (C). The sheaths for the hepatic sinusoids $(D)$ around the central vein are wider, straighter and less interconnected than those around the Glisson's sheath (see Fig. 3). $\times 300$

the sinusoids were slightly narrower, more tortuous and more extensively interconnected than their terminations in the sheaths for the central veins (Fig. 6). This arrangement of sheaths for sinusoids corresponded well with that of the sinusoids revealed by the vascular corrosion casting/SEM method (OHTANI, Murakami and Jones, 1982; OHTAni, 1989).

Collagen fibers, either with or without forming a meshwork, frequently stretched between adjacent sheaths belonging to the hepatic sinusoids (Fig. 4). These collagen fibers existed in the interhepatocytic spaces, a fact confirmed by our transmission electron microscopy of liver tissues (OHTANI, 1988). In their SEM studies MоTTA and his colleagues showed that the subendothelial spaces of Disse extended between adjacent hepatocytes, and thus form a continuous labyrinth of intercellular and perisinusoidal microlacunae (MotTa and Porter, 1974; Motta, Muto and Fujita, 1978; MotTA, 1984).
Around the central and sublobular veins were also condensations of collagen fibers that were continuous with those surrounding the hepatic sinusoids (Fig. 6). The liver capsule contained a layer $(70-100 \mu \mathrm{m}$ in thickness) consisting of interwoven collagen fibers ( 0.2 to $4 \mu \mathrm{m}$ in diameter) that were also continuous with those in the spaces of Disse.

Thus, the collagen fibers in the liver form a network continuum in the liver as a whole. The collagen fiber network so arranged undoubtedly provides the liver with a "hepato-skeletal system", a skeleton that maintains the mechanical stability of the organ.

The collagen fiber network in the liver may also play an important role in maintaining a microenvironment suitable for the activities of the organ. As generally accepted, too great an accumulation of collagen fibers, together with other extracellular matrices, will hinder the liver from keeping the microenvironment in normal conditions, and will 
hamper exchanges of substances between the blood in the sinusoids and the hepatocytes. Our preliminary study of cirrhotic livers with the cell-maceration/ SEM technique showed that collagen fibers increased not only between regenerated hepatic lobules but also in the subendothelial spaces and in the interhepatocytic spaces. The collagen fibers in the cirrhotic livers frequently formed networks surrounding the hepatocytes.

TAKAHASHI-IWANAGA and FujITA (1986), in their SEM study of alkali-collagenase treated liver tissues, showed that the fat storing cells of Ito (ITO, 1951; ITO and Nemoto, 1952) extended their attenuated processes in the interhepatocytic spaces continuous with the spaces of Disse. This and our present and previous findings (OHTANI, 1988) seem to support the hypothesis that Ito cells are responsible for producing collagen fibrils or procollagen. Indeed, evidence has accumulated that Ito cells produce collagen either in normal livers (WOOD, 1963; SCHNACK, STOCKINGER and WeWALKa, 1967; ITO and SHIBASAKI, 1968; Ito, 1973; TANIKAWA, 1975), in fibrotic livers induced by $\mathrm{CCl}_{4}$ (MC GEE and PATRICK, 1972; KENT et al., 1976; YoKOI et al., 1985), or under cultured conditions (DE LEEUW et al., 1984). It has also been reported that Ito cells increase in number in fibrotic livers induced by $\mathrm{CCl}_{4}$. However, several other cell types, including hepatocytes, have also been reported to participate in the elaboration of collagen, either in normal or in injured livers (GRIMAUD and BOROJEVIC, 1980; Diegelmann et al., 1983; Clement et al., 1984; WASSERMANN, 1958).

\section{REFERENCES}

Clara, M.: Über das argyrophile Gewebe ("Gitterfasern”) in der menschlichen Bauchspeicheldrüse. Z. Zellforsch. 39: 231-242 (1936).

Clement, B., H. Emonard, M. Rissel, M. Druguet, J.-A. Grimaud, D. Herbage, M. Bourel and A. GuILlouzo: Cellular origin of collagen and fibronectin in the liver. Cell Moll. Biol. 30: 489-496 (1984).

De Leeuw, A. M., J. E. Martindale and D. L. Knock: Cultures and cocultures of rat liver Kupffer, endothelial and fat-storing cells. In: (ed. by) D. L. KNOCK and E. WISSE: Sinusoidal liver cells. Elsevier Biomedical Press, Amsterdam-New York-Oxford, 1984 (p. 139-146).

DiegelmanN, R. F., P. S. Guzelia, R. GaY and S. GaY: Collagen formation by the hepatocyte in primary monolayer culture and in vivo. Science 219: 1343-1345 (1983).

Evan, A. P., W. G. Dail, D. Dammerose and C. PAlmer: Scanning electron microscopy of cell surface following removal of extracellular material. Anat. Rec. 185: 433446 (1976).
Grimaud, J.-A. and R. BoroJevic: Intercellular formation of collagen in human liver. Cell Moll. Biol. 26: 555562 (1980).

Highison, G. L. and F. N. Low: Microdissection by ultrasonication after prolonged $\mathrm{OsO}_{4}$ fixation: a technique for scanning electron microscopy. J. Submicrosc. Cytol. 14: 161-170 (1982).

Holmaren, E.: Über die Trophospongien der quergestreiften Muskelfasern, nebst Bemerkungen über den allgemeinen Bau dieser Fasern. Arch. Mikrosk. Anat. 71: 165-247 (1907).

Horstmann, E.: Über der Papillarkörper der menschlichen Haut und seine regionalen Unterschiede. Acta Anat. 14: 23-42 (1952).

Inoue, T. and H. Osatake: A new drying method of biological specimens for scanning electron microscopy: The t-butyl alcohol freeze-drying method. Arch. Histol. Cytol. 51: 53-59 (1988).

ITo, T.: Cytological studies on stellate cells of Kupffer and fat storing cells in the capillary wall of the human liver (Japanese abstract). Acta Anat. Nippon. 26: 42 (1951).

-: Recent advances in the study on the fine structure of the hepatic sinusoidal wall. A review. Gunma Rep. Med. Sci. 6: 119-163 (1973).

Iто, T. and N. Nemoтo: Über die Kupfferschen Sternzellen und die Blutkapillarenwand der menschlichen Leber. Okajima's Fol. Anat. Jap. 24: 243-258 (1952).

Ito, T. and S. ShIBASAKI: Electron microscopic study on the hepatic sinusoidal wall and the fat-storing cells in the normal human liver. Arch. Histol. Jap. 29: 137-192 (1968).

Kent, G. S., S. GaY, T. Inouye, R. BAHU, O. T. Minick and H. Popper: Vitamin A-containing lipocytes and formation of type III collagen in liver injury. Proc. Nat. Acad. Sci. 73: 3719-3722 (1976).

Kikuta, A., O. Ohtani and T. Murakami: Threedimensional organizsation of the collagen framework in the rat adrenal gland. Arch. Histol. Cytol. 54: 133-144 (1991).

Klein-Szanto, A. J. P. and H. E. Schroeder: Architecture and density of the connective tissue papillae of the human oral mucosa. J. Anat. 123: 93-109 (1977).

KomaI, Y. and T. Ushiki: The three-dimensional organization of collagen fibrils in the human cornea and sclera. Invest. Ophthalmol. Vis. Sci. 32: 2244-2258 (1991).

Low, F. N. and S. G. McClugage: Microdissection by ultrasonication: scanning electron microscopy of the epithelial basal lamina of the alimentary canal in the rat. Amer. J. Anat. 169: 137-147 (1984).

MarChini, M. and A. RUGGERI: Ultrastructural aspect of freeze-etched collagen fibrils. In: (ed. by) A. RUGGERI and P. M. MotTA: Ultrastructure of the connective tissue matrix. Martinus Nijhoff, Boston-The HagueDordrecht-Lancaster, 1984 (p. 89-94).

Mc Gee, J. O'D and R. S. Patrick: The role of perisinusoidal cells in hepatic fibrogenesis. An electoron microscopic study of acute carbon tetrachloride liver injury. Lab. Invest. 26: 429-440 (1972). 
Miller, B. G., R. I. Woods, H. G. Bohlen and A. P. Evan: A new morphological procedure for viewing microvessels: A scanning electron microscopic study for the vasculature of small intestine. Anat. Rec. 203: 493-503 (1982).

Miyoshi, M. and K. Shingu: Scanning electron microscope study of lymphatic tissues with special reference to the structure of the reticulum. Scan. Electron Microsc. 1984/I: 267-272 (1984).

Morita, T., T. Shimada, H. Kitamura and M. NaKaMURA: Demonstration of connective tissue sheaths surrounding working myocardial cells and Purkinje cells of the sheep moderator band. Arch. Histol. Cytol. 54: 539-550 (1991).

MotTa, P. M.: The three-dimensional microanatomy of the liver. Arch. Histol. Jap. 47: 1-30 (1984).

MotTa, P. M. and K. R. Porter: Structure of rat liver sinusoids and associated tissue spaces as revealed by scanning electron microscopy. Cell Tiss. Res. 148: 111125 (1974).

MotTa, P. M., M. Muto and T. Fujita: The liver. An atlas of scanning electron microscopy. Igaku-Shoin, Tokyo, 1978.

NAGEL, A.: Die mechanischen Eigenschaften von Perimysium internum und Sarkolemm bei der quergestreiften Muskelfasern. Z. Zellforsch. 21: 377-386 (1934).

- Die mechanischen Eigenschaften der Kapillarwand und ihre Bezeihungen zum Bindegewebslager. $Z$. Zellforsch. 22: 694-706 (1935).

Ohtani, 0.: Three-dimensional organization of the connective tissue fibers of the human pancreas. A scanning electron microscopic study of $\mathrm{NaOH}$ treated tissues. Arch. Histol. Jap. 50: 557-566 (1987).

: Three-dimensional organization of the collagen fibrillar framework of the human and rat livers. Arch. Histol. Cytol. 51: 473-488 (1988).

: Corrosion casts in liver and stomach microcirculation. In: (ed. by) P. M. MotTA: Cells and tissues: A three-dimensional approach by modern techniques in microscopy. Alan R. Liss, New York, 1989 (p. 317-326).

Ohtani, 0., A. Kikuta, A. Ohtsuka and T. Murakami: Organization of the reticular network of rabbit Peyer's patches. Anat. Rec. 229: 251-258 (1991).

Ohtani, 0., T. Murakami and A. L. Jones: Microcirculation of the liver, with special reference to the peribiliary portal system. In: (ed. by) P. M. MotTA and L. J. A. DiDio: Developments in gastroenterology, Vol. 2. Basic and clinical hepatology. Martinus Nijhoff, The Hague, 1982 (p. 85-96).
Ohtani, O., T. Ushiki, T. Taguchi and A. Kikuta: Collagen fibrillar networks as skeletal frameworks: A demonstration by cell-maceration/scanning elecrtron microscopic method. Arch. Histol. Cytol. 51: 249-261 (1988).

Plenk, H.: Über argyrophile Fasern (Gitterfasern) und ihre Bildungszellen. Ergebn. Anat. Entw.-Gesch. 27: 302-412 (1927).

Schenk, P. and J. Wersall: Die Ultrastruktur der Papillae filiformes der menschlichen Zunge. Arch. Histol. Dermatol. Forsch. 252: 91-109 (1975).

Schnack, H., L. Stockinger and F. Wewalka: Adventitious connective tissue cells in the space of Disse and their relation to fiber formation. Rev. Int. Hepatol. 17: 855-860 (1967).

Takahashi-Iwanaga, H. and T. Fujita: Application of an $\mathrm{NaOH}$ maceration method to a scanning electron micorscopic observations of Ito cells in the rat liver. Arch. Histol. Jap. 49: 349-357 (1986).

TANikawa, K.: Ultrastructure of hepatic fibrosis and fat-storing cells. In: (ed. by) H. POPPER and K. BECKER: Collagen metabolism in the liver. Stratton Intercont. Med. Book, New York, 1975 (p. 97-99).

Wassermann, F.: The structure of wall of the hepatic sinusoids in the electron microscope. Z. Zellforsch. 49: 13-32 (1958).

Wheeler, E. E., J. B. Gavin and R. N. Seelye: Freezedrying from tertiary butanol in the preparation of endocardium for scanning electron microscopy. Stain Technol. 50: 331-337 (1975).

Wood, R. L.: Evidence of species difference in the ultrastructure of the hepatic sinusoids. Z. Zellforsch. 58: 679692 (1963).

Yokol, Y., K. Matsuzaki, H. Kuroda and T. Namihisa: Distribution and morphometric determination of fatstoring cell (Ito cell) in hepatic fibrosis. In: Proc. 3rd Int. Kupffer Cell Symp., Strasbourg, 1985 (p. 267-268).

Prof. Osamu OHTAni

Department of Anatomy

Faculty of Medicine

Toyama Medical and Pharmaceutical University 2630 Sugitani, Toyama

930-01, Japan 